\title{
Evaluation of the dyeing and fastness properties of wool fabrics treated by chitosan in different molecular weights and dyed with mint
}

\section{Farklı molekül ağırlıklarında kitosan ile işlem görmüş ve nane ile boyanmış yün kumaşların boyanma ve haslık özelliklerinin değerlendirilmesi}

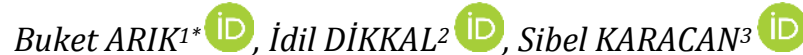

1,2,3 Textile Engineering Department, Faculty of Engineering, Pamukkale University, Denizli, Turkey. barik@pau.edu.tr, dikkal_idil@hotmail.com, sibelkaracan7@gmail.com

\begin{abstract}
Chitosan solutions were prepared by dissolving chitosan polymers, which were provided in three different molecular weight as low, medium and high, in acetic acid solution and were applied to wool fabrics. After chitosan treatment, the half of the samples were dyed with dried mint by mordanting with potassiumaluminumsulphate and another half of the samples were dyed with dried mint without mordanting. In addition, mordanted and unmordanted dyeing processes were also applied to the samples that were not treated by chitosan for comparison. Following the dyeing processes, the color values of the samples were measured via spectrophotometer by selecting the wool sample dyed with mint only as a reference. Then, the samples were exposed to washing, rubbing and light fastness tests and evaluated. Moreover, the color values of the samples after washing were measured again in order to determine the effect of washing process to color yield. From the results, it was observed that wool samples dyed with mint were in yellow and green colors and chitosan treatment had positive effects on color yield. Mordanting process caused for the wool samples to be in yellower color shades and to significant changes in color yield. Washing process decreased the color yield in all samples. Rubbing and light fastness values were found to be in acceptable limits for natural dyeing. On the other hand, chitosan treatment in different molecular weights was not found to be significant but generally medium molecular weight chitosan resulted in the most available one.
\end{abstract}

Keywords: Natural dyeing, Mint (Mentha), Mordanting Potassiumaluminumsulphate, Chitosan, Wool.

\section{Introduction}

Natural dyeing is a technique used since 4000 B.C. till now in World history and has remained its importance especially in wool and felt dyeing in present time [1]-[5]. Natural dyeing processes have been performed by extraction of natural plants or living organisms like crustaceans and by application of this extract to natural fibers like cotton, wool and silk with the help of acidic metal salts [1],[2],[4],[5]. Except for plant and animals, mineral sources like clay, ochre, ferric oxide and ultramarine pigments can also be used for natural dyeing too [4],[5]. But natural dyeing from plant sources has commonly been made due to its advantages like to be cost-effective and simple and to have much color alternatives compared to other sources [1], [6]. Using of plants as color source depends on the compounds like quinone, alkaloid, carotenoid, tannin, phenolic acid and flavonoid in their chemical structures [3],[7],[8]. In the preceding studies, it has been reported that indigo is used for

\section{Öz}

Çalıșmada düşük, orta ve yüksek olmak üzere üç farklı molekül ağırlı̆ıında kitosan polimerleri asetik asit çözeltisinde cözünerek hazırlanmış ve yün kumaşlara uygulanmıştır. Kitosan ile ön işlemin ardından kumasların yarısı Potasyum alüminyum sülfat ile mordanlandıktan sonra diğer yarısı ise mordanlanmadan kuru nane ile boyanmıștır. Ayrıca karșllaștırma amacıyla kitosan ile ișlem yapılmadan mordanlı ve mordansız boyama ișlemleri de gerçekleștirilmiștir. Boyama işlemlerinin tamamlanmasından sonra spektrofotometre aracılığı ile yün kumașların renk değerleri yalnızca nane ile boyanmış yünlü kumaş standart alınarak ölçülmüştür. Daha sonra kumaslar, yıkama, sürtme ve ısık haslığı testlerine tabi tutulmus ve değerlendirilmiștir. Ayrıca yıkama işleminin renk verimine etkisini belirlemek için numunelerin yıkama sonrası renk değerlerine de bakılmıștır. Sonuc olarak yünlü kumasların nane ile sarı ve yeșil renk tonları verdiği, kitosan ile ön işlemin renk verimine olumlu etkisinin olduğu gözlenmiștir. Mordan uygulaması, yünlü kumașların renginin sarı tonlarına yaklaşmasına ve renk veriminde belirgin bir değişime neden olmuștur. Ylkama ișlemi tüm numunelerde renk verimin düşürmüştür. Sürtme ve ışık haslık değerleri, doğal boyamalar açısından kabul edilebilir seviyelerde bulunmuştur. Diğer taraftan, farklı molekül ağırlığında kitosan uygulamasının önemli bir etkisi olmamıș ama genel anlamda orta molekül ağırlığının uygun olabileceği sonucuna ulașilmiștır.

Anahtar Kelimeler: Doğal boyama, Nane, Mordanlama, Potasyumalüminyumsülfat, Kitosan, Yün. blue, madder is used for red, indigo-madder mixture is used for purple, turmeric, buckthorn and reseda are used for yellow, indigo-reseda mixture is used for green and chamomilemadder mixture is used for orange color [2]-[4]. Natural dye plants are advantageous against synthetic dyes due to the fact that they do not have toxic, allergic and carcinogen effects and do not cause environmental pollution [2],[4]-[6],[8]-[14]. Moreover, some of these plants also have antimicrobial, antibacterial, antifungal, antioxidant and UV protection properties [2],[4],[10],[13],[15]-[18].

Mint that is a kind of plant belonged to the Lamiaceae (Labiatae) family is also general name for Mentha species [2], [16],[17]. There are three important mint species cultivated in the World as Pepper mint (Mentha Piperita), Japanese mint (Mentha Arvensis) and Spear mint (Mentha spicata). Apart from these, there are also some special mint species too. The production of mint is quite simple and can be made by seed, tiller and stem. After harvesting, the crop is dried in dark area 
or by special drying systems [17]. Mint, which is generally used for getting essential oil and spice, can also be used for textile dyeing to obtain khaki, dark green, yellow, pale yellow or brown colors depending on the content of mordant materials as reported in the previous studies [2],[4],[11],[16],[19].

Most of the natural dyes do not affinity to textile fibers and as a result of this fact, their bondings to the fibers are weak by hydrogen bonds and hydrophobic interactions [2],[4],[9]. Acidic metal salts, in other words, mordant materials are used to enable bonding and this bonding process of these materials to textile fibers is called as mordanting [2],[3],[9],[10],[12], [20]. Metal salts lead natural dyes to adsorb on the fiber surface and to become complex. So that, color yields and fastness properties of dyed textile surfaces are improved [3],[6],[9], [12],[13],[20]. In addition, different colors or different shades of the same color can also be obtained by using different mordant materials with one kind of extract [6],[9],[12],[20]. On the other hand, besides the much color alternatives, they have some disadvantages like having carcinogen or toxic properties, causing ecological problems and being inadequate and these disadvantages limit their applications [2],[21]. Among the metal salts, potassiumaluminumsulphate is known to be the most preferred mordant material due to be abundant, pure, ecologic and to enable bright color shades [2],[4],[21].

Chitosan is natural biopolymer and can be obtained by deacetylation of the chitin that exists in the crab and shrimp shells [15],[18],[22]-[26]. The molecular weight of chitin and chitosan can alter depending on the source and deacetylation degree and this fact directly affects the solubility, film forming ability and bonding properties of the chitin and chitosan [22]-[24]. For instance, chitosan can easily be solved in acidic $\mathrm{pH}$ values while chitin can not be solved in many organic solvents [15],[22]-[25]. To make the chitosan dissolved, generally formic acid, acetic acid and lactic acid have been used [23],[25]. Among these, the most preferred one is acetic acid as reported in the literature [15],[23]. Chitosan can be used in many textile processes, e.g. antimicrobial finishing, dyeing improvement and antifelting of wool via its distinctive properties as nontoxicity, biodegradability and reactivity with anionic materials due to the cationic chemical structure [4],[15],[18],[22]-[28].

The effect of chitosan treatment on wool dyeing was studied before by a few studies. For instance, Mohamed et al. 2015 evaluated the dyeability and antimicrobial activity of wool fibers pretreated with chitosan and dyed with synthetic (reactive) dyes and compared the chitosan application in different molecular weights for reactive dyeing [29]. Giri Dev et al. 2009 applied natural (henna) dye along with chitosan to impart antimicrobial characteristics and to increase dye uptake of wool fabrics [30]. Arik et al. 2012 studied the effect of chitosan on natural dyeability and antibacterial activity of wool fabrics and used natural dye plant, Reseda Luteola [31]. But in these two studies, the effects of the chitosan in different molecular weights were not compared in detail for natural dyeing. Moreover, natural dyeing with mint was not much studied as well. Kızıl and Kayabaşı, 2006; Tutak et al. 2014 and Eser et al. 2017 investigated the dyeing potential of dried and fresh forms of mint on wool fibers [11],[16],[19]. But they did not apply chitosan. So, dissimilarly from preceding studies, in this study, the effects of chitosan in different molecular weights on dyeing and fastness properties of wool fabric before natural dyeing with mint were firstly evaluated.

\section{Material and method}

\subsection{Material}

Mill scoured and washed 100\% wool fabric weighing $166 \mathrm{~g} / \mathrm{m}^{2}$ (warp: 30 thread/cm, weft: 30 thread/cm) was used in this study. Dried mint (Mentha spicata) was supplied from local store as a natural colorant and potassiumaluminumsulphate was supplied from Merck as a mordanting material. Chitosan polymers in different molecular weights as low (Molecular weight: $70000 \mathrm{Da}$ and Deacetylation degree: 83.7\%), medium (Molecular weight: $150000 \mathrm{Da}$ and Deacetylation degree: 85.5\%) and high (Molecular weight: $375000 \mathrm{Da}$ and Deacetylation degree: 87.8\%) were purchased from Sigma Aldrich and acetic acid (98\%) used for dissolution of chitosan was supplied from Merck.

\subsection{Method}

\subsubsection{Chitosan pretreatment}

Three different chitosan polymers as low, medium and high molecular weights were taken in two concentrations $(0.5$ and $2 \% \mathrm{w} / \mathrm{v})$, added to acetic acid solution in the concentration of $2 \% \mathrm{v} / \mathrm{v}$ and stirred in room temperature till ensuring the homogenity. The wool fabrics were dipped in the solutions, padded with the wet pick up of $80 \%$ in laboratory type horizontal padding machine (Prowhite Y002), dried at $90{ }^{\circ} \mathrm{C}$ for $3 \mathrm{~min}$. and finally cured at $150{ }^{\circ} \mathrm{C}$ for $1 \mathrm{~min}$. in laboratory type stenter (Prowhite Y003).

\subsubsection{Mordanting}

Potassiumaluminumsulphate $\left(\mathrm{KAl}\left(\mathrm{SO}_{4}\right)_{2} .12 \mathrm{H}_{2} \mathrm{O}\right)$ was used as mordanting material and pre-mordanting method was applied to wool fabric. For this aim, mordant was taken as $20 \%$ (w/w) of wool weight and liquor ratio was adjusted as 1:30. Mordanting process was carried out at $100{ }^{\circ} \mathrm{C}$ for $60 \mathrm{~min}$. in laboratory type dyeing machine (SandoLab SUPERMAT 6). Following, mordanted wool fabric samples were allowed to dry in room temperature.

\subsubsection{Mint dyeing}

For dyeing process, dried mint leaves were prepared as $50 \%$ $(\mathrm{w} / \mathrm{w})$ of wool weight and liquor ratio was adjusted as 1:30. Dyeing process was carried out at $100{ }^{\circ} \mathrm{C}$ for $60 \mathrm{~min}$. in laboratory type dyeing machine (SandoLab SUPERMAT 6). Then, dyed wool fabric samples were cleaned from the mint residues by washing and allowed to dry in room temperature.

\subsubsection{Color measurement}

The colorimetric data of the samples were measured according to CIE Lab standart methods in spectrophotometer (Datacolor $\left.600^{\mathrm{TM}}\right) . K / S$ values were calculated using the Kubelka-Munk equation as follows;

$$
K / S=(1-R)^{2} / 2 R
$$

Where $(K)$ is the adsorption coefficient, $(R)$ is the reflectance and $(S)$ is the scattering coefficient. In addition, $\operatorname{CIE~} L^{*}, a^{*}, b^{*}$, $C^{*}, h^{\circ}, d E^{*}$ values were also determined where $L^{*}$ is lightness, $a^{*}$ is redness (+ve) or greenness (-ve), $b^{*}$ is yellowness (+ve) or blueness (-ve), $C^{*}$ is chroma, $h^{\circ}$ is hue angle and $d E^{*}$ is total color difference. For each sample, five measurements were made and mean values were calculated. 


\subsubsection{Washing fastness test}

Washing fastness test was carried out according to ISO 105:C06 A2S standard method at $40^{\circ} \mathrm{C}$ for $30 \mathrm{~min}$. with $4 \mathrm{~g} / \mathrm{L}$ standart detergent (ECE) in SDL ATLAS M228 Rotawash machine. The change in colour and staining were evaluated using a grey scale between 1 and 5 .

\subsubsection{Rubbing fastness test}

Rubbing fastness test was carried out according to ISO 105:X12 standard method as dry and wet in James Heal machine and evaluated using a grey scale between 1 and 5 .

\subsubsection{Light fastness test}

Light fastness test was carried out according to ISO 105:B02 standard method and evaluated using a blue scale between 1 and 8 .

\section{Results and discussion}

\subsection{Colorimetric data results}

In the study, dried mint leaves as natural colorant and potassiumaluminumsulphate as a mordanting material were used. Moreover, treatment with chitosan polymers in different molecular weights was also applied to wool fabrics before dyeing and the effects were evaluated.

The colors of mint dyed samples are given in Table 1 .

According to the Table 1, mint dyed wool fabrics were found to be in khaki, dirty yellow and mustard yellow colors. It was clearly observed that mordanting process caused the colors to be in yellower shades and chitosan treatment caused high color yield. This fact confirmed the results of related studies [16],[29],[30],[31].

It has already known that mint type of Mentha spicata is rich in carvone that is a kind of terpenoid [16]. In this study, the colors of the mint dyed samples were attributed to this compound and the color change after mordanting was thought to be due to the change in light absorption and reflectance properties depending on the complex formation of carvone with metal ion of mordant.

Wool fabrics catch anionic dyestuffs via their amine $\left(-\mathrm{NH}_{2}\right)$ groups and mordanting materials strength this bonding by bridging the auxochrome groups of dyestuffs to wool samples [3]. On the other hand, chitosan biopolymer is adsorbed to wool by hydrogen bonding, electrostatic forces and Van der Waals interactions and increases the dye adsorption on the wool surface due to its amine (- $\left.\mathrm{NH}_{2}\right)$ groups [18]. So, darker colors in higher chitosan concentration was attributed to this fact.

Since the mordanting process leaded to change in color shades, the colorimetric data were separately evaluated for mordanted and for unmordanted samples. Thereby, the colorimetric data for unmordanted samples before washing and after washing are given in Tables 2 and 3 respectively, while the colorimetric data for mordanted samples before washing and after washing are given in Tables 4 and 5 respectively.

Without mordanting, dark green and dirty yellow colors were obtained in the mint dyed wool samples and that $h^{\circ}$ (hue angle) was between $85^{\circ}$ and $92^{\circ}$ verified this fact. When the $K / S$ (color strength) values were considered, it was observed that chitosan treatment leaded to increase in color yield. Moreover, the increase in chitosan concentration provided darker colors, so that it was concluded that it should be studied with high chitosan concentration for dark colors. When the molecular weights of the chitosan polymers were compared, it was found that although there were no significant differences, medium molecular weight chitosan could be more available. The highest color yield was provided by the medium molecular weight chitosan in $2 \%$ concentration. $L^{*}$ (lightness) values decreased depending on the increase in color darkness. $a^{*}$ values passed from negative values to positive values that mean greenness decreased and redness increased. $b^{*}$ values kept on the positive values in the positive direction, so yellowness increased while blueness decreased. $C^{*}$ (chroma) and $d E^{*}$ (total color difference) values were found to increase in parallel with color yield too.

Dyed samples were subjected to washing process and their colorimetric data were measured again. Accordingly, decreases in color yield were observed after washing. This fact was attributed to the ionation of hydroxyl groups of dye molecules and decomposition of some part of the dyestuff because of the alkaline medium of standart detergent solution as reported in another study [16]. $L^{*}$ values increased accordingly to the decrease in color yield. Since $a^{*}$ values increased with respect to before washing, it was determined that greenness decreased. $b^{*}$ values also increased with respect to before washing, so the yellowness tendency in color shade was proved. $h^{\circ}$ values verified this tendency too. $C^{*}$ and $d E^{*}$ values changed in accordance with color yield. In mordanted and mint dyed samples, the colors were found to be bright dark green and mustard yellow and that $h^{\circ}$ (hue angle) was between $83^{\circ}$ and $87^{\circ}$ verified this fact. Color strength $(K / S)$ values were found to be quite high when compared to unmordanted samples and chitosan treatment promoted this increase. The change in molecular weight of chitosan polymer was resulted to be insignificant since usage of different molecular weight chitosan polymers did not show distint difference. The fact that $L^{*}$ values were higher than unmordanted samples showed that the mordanting process leaded to bright and vivid colors. Since $a^{*}$ values increased, it was determined that greenness decreased and redness increased. $b^{*}$ values clearly increased in comparison with unmordanted samples and confirmed the evident change in yellowness. $C^{*}$ and $d E^{*}$ values were found to increase in parallel with color yield too. After washing process, decrease in color yield in mordanted samples was observed similarly to the unmordanted samples. Decrease in color yield caused $L^{*}$ values to increase. $a^{*}$ and $b^{*}$ values increased when compared to the samples before washing and showed that greenness decreased and yellowness increased. $C^{*}$ and $d E^{*}$ values changed in accordance with color yield.

\subsection{Washing fastness test results}

Washing fastness test results of the unmordanted dyed samples are given in Table 6 while washing fastness test results of the mordanted dyed samples are given in Table 7. Color change of the unmordanted dyed samples were evaluated as medium level. Chitosan treatment did not cause any important change. On the other hand, the washing fastness values for staining were evaluated as quite good. Color change of the mordanted dyed samples were evaluated as medium and low. Especially, the color of the sample without chitosan treatment was quite different. But in the chitosan treated samples color change showed one point improvement and this fact showed positive effect of chitosan treatment in mordanted dyeing to washing. On the other hand, the washing fastness values for staining were evaluated as quite good likewise the unmordanted dyed samples. 
Table 1. The colors of the mint dyed samples.

\begin{tabular}{|c|c|c|c|c|c|}
\hline Sample & Before Washing & After Washing & Sample & Before Washing & After Washing \\
\hline $\begin{array}{l}0.5 \% \text { LMWC treated } \\
\text { and mint dyed }\end{array}$ & & & $\begin{array}{l}\text { 2\% LMWC treated } \\
\text { and mint dyed }\end{array}$ & & \\
\hline $\begin{array}{l}\text { 0.5\% LMWC treated, } \\
\text { mordanted and mint } \\
\text { dyed }\end{array}$ & & & $\begin{array}{l}\text { 2\% LMWC treated, } \\
\text { mordanted and mint } \\
\text { dyed }\end{array}$ & & \\
\hline $\begin{array}{l}0.5 \% \text { MMWC treated } \\
\text { and mint dyed }\end{array}$ & & & $\begin{array}{l}2 \% \text { MMWC treated } \\
\text { and mint dyed }\end{array}$ & & \\
\hline $\begin{array}{c}0.5 \% \text { MMWC treated, } \\
\text { mordanted and mint } \\
\text { dyed }\end{array}$ & & & $\begin{array}{l}\text { 2\% MMWC treated, } \\
\text { mordanted and mint } \\
\text { dyed }\end{array}$ & & \\
\hline $\begin{array}{l}0.5 \% \text { HMWC treated } \\
\text { and mint dyed }\end{array}$ & & & $\begin{array}{l}2 \% \text { HMWC treated } \\
\text { and mint dyed }\end{array}$ & & \\
\hline $\begin{array}{c}0.5 \% \text { HMWC treated, } \\
\text { mordanted and mint } \\
\text { dyed }\end{array}$ & & & $\begin{array}{l}\text { 2\% HMWC treated, } \\
\text { mordanted and mint } \\
\text { dyed }\end{array}$ & & \\
\hline
\end{tabular}

LMWC: Low molecular weight chitosan, MMWC: Medium molecular weight chitosan, HMWC: High molecular weight chitosan.

Table 2. Colorimetric data of the unmordanted mint dyed samples before washing.

\begin{tabular}{|c|c|c|c|c|c|c|c|}
\hline Sample & $K / S$ & $L^{*}$ & $a^{*}$ & $b^{*}$ & $C^{*}$ & $h^{\circ}$ & $d E^{*}$ \\
\hline Mint dyed only & 6.76 & 57.41 & -0.91 & 20.97 & 22.88 & 92.33 & Reference \\
\hline $0.5 \%$ LMWC treated and mint dyed & 7.30 & 53.52 & 2.48 & 24.75 & 25.18 & 85.76 & 5.26 \\
\hline $0.5 \%$ MMWC treated and mint dyed & 8.03 & 51.99 & 2.31 & 24.12 & 25.88 & 86.65 & 7.83 \\
\hline $0.5 \%$ HMWC treated and mint dyed & 7.41 & 53.13 & 2.38 & 24.21 & 25.70 & 86.55 & 6.18 \\
\hline 2\% LMWC treated and mint dyed & 8.83 & 49.32 & 1.59 & 23.67 & 25.16 & 88.15 & 8.58 \\
\hline $2 \%$ MMWC treated and mint dyed & 9.26 & 47.98 & 1.53 & 23.19 & 26.79 & 89.31 & 9.38 \\
\hline $2 \%$ HMWC treated and mint dyed & 8.92 & 49.12 & 1.58 & 23.58 & 26.29 & 88.30 & 9.15 \\
\hline
\end{tabular}

LMWC: Low molecular weight chitosan, MMWC: Medium molecular weight chitosan, HMWC: High molecular weight chitosan 
Table 3. Colorimetric data of the unmordanted mint dyed samples after washing.

\begin{tabular}{|c|c|c|c|c|c|c|c|}
\hline Sample & $K / S$ & $L^{*}$ & $a^{*}$ & $b^{*}$ & $C^{*}$ & $h^{\circ}$ & $d E^{*}$ \\
\hline Mint dyed only & 6.31 & 58.41 & 1.87 & 22.80 & 20.99 & 85.30 & Reference \\
\hline $0.5 \%$ LMWC treated and mint dyed & 6.51 & 56.33 & 2.95 & 26.69 & 24.36 & 84.04 & 2.95 \\
\hline $0.5 \%$ MMWC treated and mint dyed & 6.72 & 55.19 & 2.46 & 25.05 & 24.79 & 84.46 & 3.49 \\
\hline $0.5 \%$ HMWC treated and mint dyed & 6.53 & 55.39 & 2.84 & 25.84 & 24.75 & 84.18 & 3.38 \\
\hline $2 \%$ LMWC treated and mint dyed & 7.22 & 53.23 & 2.16 & 26.11 & 25.16 & 84.80 & 3.91 \\
\hline $2 \%$ MMWC treated and mint dyed & 7.96 & 51.09 & 2.05 & 24.93 & 26.49 & 85.15 & 4.72 \\
\hline $2 \%$ HMWC treated and mint dyed & 7.72 & 52.40 & 2.07 & 25.80 & 26.26 & 84.91 & 4.46 \\
\hline
\end{tabular}

LMWC: Low molecular weight chitosan, MMWC: Medium molecular weight chitosan, HMWC: High molecular weight chitosan.

Table 4. Colorimetric data of the mordanted mint dyed samples before washing.

\begin{tabular}{|c|c|c|c|c|c|c|c|}
\hline Sample & $K / S$ & $L^{*}$ & $a^{*}$ & $b^{*}$ & $C^{*}$ & $h^{\circ}$ & $d E^{*}$ \\
\hline Mint dyed only & 6.76 & 57.41 & -0.91 & 20.97 & 22.88 & 92.33 & Reference \\
\hline Mordanted and mint dyed & 20.30 & 56.39 & 2.79 & 35.94 & 38.29 & 83.72 & 19.13 \\
\hline $\begin{array}{l}0.5 \% \text { LMWC treated, mordanted and } \\
\text { mint dyed }\end{array}$ & 21.61 & 55.07 & 3.45 & 35.24 & 39.17 & 84.89 & 21.97 \\
\hline $\begin{array}{l}0.5 \% \text { MMWC treated, mordanted and } \\
\text { mint dyed }\end{array}$ & 23.50 & 54.47 & 2.96 & 33.69 & 42.98 & 86.75 & 23.66 \\
\hline $\begin{array}{l}0.5 \% \text { HMWC treated, mordanted and } \\
\text { mint dyed }\end{array}$ & 23.11 & 54.82 & 3.20 & 34.08 & 42.15 & 85.59 & 22.12 \\
\hline $\begin{array}{l}\text { 2\% LMWC treated, mordanted and } \\
\text { mint dyed }\end{array}$ & 23.02 & 54.89 & 2.58 & 33.73 & 41.96 & 85.15 & 22.06 \\
\hline $\begin{array}{l}\text { 2\% MMWC treated, mordanted and } \\
\text { mint dyed }\end{array}$ & 23.67 & 54.16 & 2.39 & 33.10 & 43.16 & 87.41 & 24.79 \\
\hline $\begin{array}{l}2 \% \text { HMWC treated, mordanted and } \\
\text { mint dyed }\end{array}$ & 23.62 & 54.49 & 2.46 & 33.38 & 43.10 & 85.92 & 22.64 \\
\hline
\end{tabular}

LMWC: Low molecular weight chitosan, MMWC: Medium molecular weight chitosan, HMWC: High molecular weight chitosan.

Table 5. Colorimetric data of the mordanted mint dyed samples after washing.

\begin{tabular}{|c|c|c|c|c|c|c|c|}
\hline Sample & $K / S$ & $L^{*}$ & $a^{*}$ & $b^{*}$ & $C^{*}$ & $h^{\circ}$ & $d E^{*}$ \\
\hline Mint Dyed only & 6.31 & 58.41 & 1.87 & 22.80 & 20.99 & 85.30 & Reference \\
\hline Mordanted and mint dyed & 13.32 & 57.73 & 3.92 & 43.00 & 33.26 & 84.15 & 11.47 \\
\hline $\begin{array}{l}0.5 \% \text { LMWC treated, mordanted and } \\
\text { mint dyed }\end{array}$ & 14.26 & 57.56 & 3.91 & 44.16 & 33.45 & 84.74 & 11.82 \\
\hline $\begin{array}{l}0.5 \% \text { MMWC treated, mordanted and } \\
\text { mint dyed }\end{array}$ & 15.70 & 55.80 & 3.56 & 43.14 & 34.10 & 84.95 & 12.02 \\
\hline $\begin{array}{l}0.5 \% \text { HMWC treated, mordanted and } \\
\text { mint dyed }\end{array}$ & 15.19 & 56.68 & 3.74 & 42.93 & 33.86 & 84.76 & 11.87 \\
\hline $\begin{array}{l}\text { 2\% LMWC treated, mordanted and } \\
\text { mint dyed }\end{array}$ & 15.30 & 56.09 & 2.98 & 41.79 & 33.87 & 84.88 & 11.90 \\
\hline $\begin{array}{l}\text { 2\% MMWC treated, mordanted and } \\
\text { mint dyed }\end{array}$ & 16.55 & 54.88 & 2.63 & 40.34 & 36.05 & 85.18 & 12.61 \\
\hline $\begin{array}{l}\text { 2\% HMWC treated, mordanted and } \\
\text { mint dyed }\end{array}$ & 15.92 & 55.19 & 2.75 & 41.43 & 35.37 & 84.97 & 12.13 \\
\hline
\end{tabular}

LMWC: Low molecular weight chitosan, MMWC: Medium molecular weight chitosan, HMWC: High molecular weight chitosan.

Table 6. Washing fastness test results of the unmordanted dyed samples.

\begin{tabular}{|c|c|c|c|c|c|c|c|}
\hline \multirow{2}{*}{ Sample } & \multirow{2}{*}{ Color Change } & \multicolumn{6}{|c|}{ Staining } \\
\hline & & Wool & Polyacrylnitril & Polyester & Polyamide & Cotton & Acetate \\
\hline Mint dyed only & 3 & $4-5$ & 5 & 5 & 5 & 4-5 & 5 \\
\hline $0.5 \%$ LMWC treated and mint dyed & $3-4$ & $4-5$ & 5 & 5 & 5 & $4-5$ & 5 \\
\hline $0.5 \%$ MMWC treated and mint dyed & $3-4$ & $4-5$ & 5 & 5 & 5 & $4-5$ & 5 \\
\hline $0.5 \%$ HMWC treated and mint dyed & $3-4$ & $4-5$ & 5 & 5 & 5 & $4-5$ & 5 \\
\hline $2 \%$ LMWC treated and mint dyed & 3 & 5 & 5 & 5 & 5 & 5 & 5 \\
\hline $2 \%$ MMWC treated and mint dyed & 3 & 5 & 5 & 5 & 5 & $4-5$ & 5 \\
\hline $2 \%$ HMWC treated and mint dyed & 3 & 5 & 5 & 5 & 5 & 5 & 5 \\
\hline
\end{tabular}

LMWC: Low molecular weight chitosan, MMWC: Medium molecular weight chitosan, HMWC: High molecular weight chitosan.

Table 7. Washing fastness test results of the mordanted dyed samples.

\begin{tabular}{|c|c|c|c|c|c|c|c|}
\hline \multirow{2}{*}{ Sample } & \multirow{2}{*}{$\begin{array}{c}\text { Color } \\
\text { Change }\end{array}$} & \multicolumn{6}{|c|}{ Staining } \\
\hline & & Wool & Polyacrylnitril & Polyester & Polyamide & Cotton & Acetate \\
\hline Mordanted and mint dyed & 2 & $4-5$ & 5 & 5 & 5 & $4-5$ & 5 \\
\hline $0.5 \%$ LMWC treated, mordanted and mint dyed & 3 & 5 & 5 & 5 & 5 & 5 & 5 \\
\hline $0.5 \%$ MMWC treated, mordanted and mint dyed & 3 & 5 & 5 & 5 & 5 & 5 & 5 \\
\hline $0.5 \%$ HMWC treated, mordanted and mint dyed & 3 & 5 & 5 & 5 & 5 & 5 & 5 \\
\hline 2\% LMWC treated, mordanted and mint dyed & 3 & 5 & 5 & 5 & 5 & 5 & 5 \\
\hline $2 \%$ MMWC treated, mordanted and mint dyed & 3 & 5 & 5 & 5 & 5 & 5 & 5 \\
\hline 2\% HMWC treated, mordanted and mint dyed & 3 & 5 & 5 & 5 & 5 & 5 & 5 \\
\hline
\end{tabular}

LMWC: Low molecular weight chitosan, MMWC: Medium molecular weight chitosan, HMWC: High molecular weight chitosan. 


\subsection{Rubbing and light fastness test results}

Rubbing and light fastness results of the unmordanted dyed samples are given in Table 8 , while rubbing and light fastness results of the mordanted dyed samples are given in Table 9.

Dry rubbing fastness values were evaluated as good in unmordanted dyed samples. Since wet rubbing fastness values were lower than dry rubbing fastness values, wet rubbing fastness values were evaluated as medium and good.

Chitosan treatment leaded to decrease in rubbing fastness of unmordanted samples and this was attributed to the fact that chitosan treated samples had darker colors than mint dyed only. Light fastness values of unmordanted samples were found to be moderate for natural dyeing and chitosan treatment did not cause any significant change. Only, the light fastness values of the $2 \%$ medium molecular weight and $2 \%$ high molecular weight chitosan treated samples were found to be low in comparison with the others due to the high color yield $(K / S)$ and chroma $\left(C^{*}\right)$ values as reported in other studies about natural dyeing [9],[16],[32].

Rubbing fastness values of mordanted dyed samples were evaluated as medium in general. The highest rubbing fastness values were obtained in the sample without chitosan treatment. In the other samples, the rubbing fastness values decreased to medium levels, so it was concluded that chitosan treatment affected negatively the rubbing fastness. Light fastness values were found to be quite close to the values of unmordanted dyed samples, so it was understood that mordanting process had no prominent impact on light fastness. Similarly, chitosan treatment did not cause any significant change in the light fastness too.

\section{Conclusion}

The wool fabrics treated by chitosan polymers in different molecular weights were dyed with dried mint by mordanting and unmordanting. While in the samples dyed without mordanting the colors were dark green and dirty yellow, brighter and yellower shades were obtained in the samples dyed by mordanting. Chitosan treatment affected positively the color yield and washing fastness of the mordanted dyed samples. High chitosan concentration leaded to high color yield. Washing process caused decreases in color yields due to the deteriorative effect of detergent. Rubbing and light fastness values were found to be in medium and good levels. When the molecular weight difference of chitosan polymers was considered, it was observed that medium molecular weight chitosan could be available despite the little differences. Consequently, it was concluded that mordanting process was important in terms of color yield and chitosan treatment had positive contributions regardless of molecular weight. Moreover, this study was significant in terms of sustainable environment owing to the fact that natural, ecological and human health sensitive materials were used.

\section{References}

[1] Kılıçarslan H. The Colors Obtained From Fir (Abies) Cone And The Fastness Values of These Colors on Wool Carpet Yarns. MSc. Thesis, Ankara University, Ankara, Turkey, 2006.

[2] Karadag R. Natural Dyeing. 1st ed. Ankara, Turkey, Republic of Turkey Ministry of Culture and Tourism, 2007.

[3] Benli H. "Wool yarns dyed with madder red and buckthorn used in turkish carpets and improvement of fastness". Arış, 7(7), 18-25, 2012.

[4] Karabulut K. Giving color, UV protection and antibacterial activity in a single step to knitted cotton fabrics via dyeing with natural dyes. MSc. Thesis, Namık Kemal University, Tekirdag, Turkey, 2015.

[5] Taylan M, Atlihan Ş. "Usage of natural fibers and natural dyes in textile designing". Idil, 7(43), 319-326, 2018.

[6] Yllmaz F, Bahtiyari Mİ. "Coloration of wool fabrics with various plantal sources". Journal of Textiles and Engineer, 24(106), 62-71, 2017.

[7] Lubbe A, Verpoorte R. "Cultivation of medicinal and aromatic plants for specialty industrial materials". Industrial Crops and Products, 34(1), 785-801, 2011.

[8] Ismal OE. "Greener natural dyeing pathway using a by-product of olive oil; prina and biomordants". Fibers and Polymers, 18(4), 773-785, 2017.

Table 8. Rubbing and light fastness results of the unmordanted dyed samples.

\begin{tabular}{|c|c|c|c|}
\hline \multirow{2}{*}{ Sample } & \multicolumn{2}{|c|}{ Rubbing } & \multirow[b]{2}{*}{ Light } \\
\hline & Dry & Wet & \\
\hline Mint dyed only & 5 & $4-5$ & 5 \\
\hline $0.5 \%$ LMWC treated and mint dyed & $4-5$ & 4 & 5 \\
\hline $0.5 \%$ HMWC treated and mint dyed & $4-5$ & 3 & $4-5$ \\
\hline $2 \%$ LMWC treated and mint dyed & 4 & $3-4$ & $4-5$ \\
\hline $2 \%$ MMWC treated and mint dyed & 4 & 3 & 4 \\
\hline $2 \%$ HMWC treated and mint dyed & 4 & 3 & 4 \\
\hline
\end{tabular}

LMWC: Low molecular weight chitosan, MMWC: Medium molecular weight chitosan, HMWC: High molecular weight chitosan

Table 9. Rubbing and light fastness results of the mordanted dyed samples.

\begin{tabular}{lcc}
\hline \multicolumn{1}{c}{ Sample } & Rubbing & Wet \\
\cline { 2 - 3 } Light & $4-5$ \\
Mordanted and mint dyed & $4-5$ & 4 \\
$0.5 \%$ LMWC treated, mordanted and mint dyed & 4 & $3-4$ \\
$0.5 \%$ MMWC treated, mordanted and mint dyed & 4 & $3-4$ \\
$0.5 \%$ HMWC treated, mordanted and mint dyed & 4 & $3-4$ \\
2\% LMWC treated, mordanted and mint dyed & 4 & 3 \\
2\% MMWC treated, mordanted and mint dyed & $3-4$ & $3-5$ \\
2\% HMWC treated, mordanted and mint dyed & $3-4$ & $4-5$ \\
\hline
\end{tabular}

$3-4$

LMWC: Low molecular weight chitosan, MMWC: Medium molecular weight chitosan, HMWC: High molecular weight chitosan. 
[9] Tutak M, Benli H. "Investigation of dyeing properties of natural dyes obtained from some plants on wool". Journal of Balikesir University Institute of Science and Technology, 10(2), 53-59, 2008.

[10] Rungruangkitkrai N, Mongkholrattanasit R. "Eco-friendly of textiles dyeing and printing with natural dyes". RMUTP International Conference: Textiles \& Fashion, Bangkok, Thailand, 3-4 July 2012.

[11] Tutak M, Acar G, Akman 0. "Natural dyeing of wool fiber using mint (Mentha Spicata L.) and thyme (Thymus Vulgaris L.)". Journal of Textiles and Engineer, 21(93), 18-23, 2014.

[12] Zubairu A, Msheila YM. "Effects of selected mordants on the application of natural dye from onion skin (Allium cepa)". Science and Technology, 5(2), 26-32, 2015.

[13] Gawish SM, Mashaly HM, Helmy HM, Ramadan AM, Farouk R. "Effect of mordant on UV protection and antimicrobial activity of cotton, wool, silk and nylon fabrics dyed with some natural dyes". Journal of Nanomedicine \& Nanotechnology, 8(1), 1-9, 2017.

[14] Nurunnesa B, Hossain MdA, Rahman MdM. "Extraction of natural dye collected from outer skin of onion and it's application on silk fabric". Global Journal of Researches in Engineering: J General Engineering, 18(3), 1-7, 2018.

[15] Joshi M, Ali SW, Purwar R, Rajendran S. "Ecofriendly antimicrobial finishing of textiles using bioactive agents based on natural products". Indian Journal of Fibre \& Textile Research, 34(3), 295-304, 2009.

[16] Eser F, Telci I, Yilmaz F, Temiz C, Aktas E, Onal A. "Determination of the dyeing potential of mint and sage crops wastes on wool and cotton fibers". Journal of Natural Fibers, 14(4), 564-573, 2017.

[17] Karakaplan N. Investigation of Optimum Conditions for Obtain Essential Oils From Mint (Mentha spicata). MSc. Thesis, Inonu University, Malatya, Turkey, 2017.

[18] Islam S, Butola BS, Roy A. "Chitosan polysaccharide as a renewable functional agent to develop antibacterial, antioxidant activity and colourful shades on wool dyed with tea extract polyphenols". International Journal of Biological Macromolecules, 120(2), 1999-2006, 2018.

[19] Kızıl S, Kayabaşı N. "Determination of dyeing properties of spearmint (Mentha spicata var. spicata)". International Journal of Agriculture \& Biology, 8(4), 496-498, 2006.

[20] Moniruzzaman Md, Mondal MS, Hossain MdN. "The influence of mordant and mordanting techniques on ecofriendly dyeing of cotton fabric by extracted used tea". Journal of Engineering Science, 9(1), 111-117, 2018.
[21] Ismal OE. "Patterns from nature: contact printing". Journal of the Textile Association, 77(2), 81-91, 2016.

[22] Pascual E, Julia MR. "The role of chitosan in wool finishing". Journal of Biotechnology, 89(2-3), 289-296, 2001.

[23] Demir A. A Research on Usage Possibilities of Chitin and Chitosan in Textile Finishing. PhD Thesis, Ege University, Izmir, Turkey, 2007.

[24] Enescu D. "Use of chitosan in surface modification of textile materials". Roumanian Biotechnological Letters, 13(6), 4037-4048, 2008.

[25] Bulut MO, Elibüyük U. "Production of chitosan the crab chitin". Erzincan University Journal of Science and Technology, 10(2), 213-219, 2017.

[26] Reshma A, Priyadarisini VB, Amutha K. "Sustainable antimicrobial finishing of fabrics using natural bioactive agents - A Review". International Journal of Life Science and Pharma Research, 8(4), 10-20, 2018.

[27] Demir A, Seventekin N. "Chitin, chitosan and general application areas". Electronic Journal of Textile Technologies, 3(2), 92-103, 2009.

[28] Ammayappan L. "Eco-friendly surface modifications of wool fiber for its improved functionality: An Overview". Asian Journal of Textile, 3(1), 15-28, 2013.

[29] Mohamed FA, Ali NF, El-Mohamedy RSR. "The dye ability and antimicrobial activity of wool fibers dyed with reactive dyes and pre- treated with chitosan". International Journal of Current Microbiology and Applied Sciences, 4(11), 587-596, 2015.

[30] Giri Dev VR, Venugopal J, Sudha S, Deepika G, Ramakrishna S. "Dyeing and antimicrobial characteristics of chitosan treated wool fabrics with henna dye". Carbohydrate Polymers, 75(4), 646-650, 2009.

[31] Arik B, Sahan G, Demir A, Seventekin N. "Effect of chitosan on natural dyeability and antibacterial activity of wool fabrics". 1 1st International Fashion and Textile Design Symposium, Antalya, Turkey, 8-10 October 2012.

[32] Ghouila H, Meksi N, Haddar W, Mhenni MF, Jannet HB. "Extraction, identification and dyeing studies of Isosalipurposide, a natural chalcone dye from Acacia cyanophylla flowers on wool". Industrial Crops and Products, 35(1), 31-36, 2012. 